Article

\title{
Optimizing the Use of Digital Marketing for Increasing Sales Volume at MSMEs in Mataram, Indonesia
}

\author{
Abdurrahman, Rini Anggriani, Raden Bagus Faizal IS* \\ Department of Management, Bumigora University, Mataram, Indonesia \\ *Correspondence: abdurrahman@universitasbumigora.ac.id
}

\begin{abstract}
The aim of this research was to determine the effect of digital marketing for increasing sales volume for Micro, Small and Medium Enterprises (MSME's) in Mataram, Indonesia. The sampling technique in this research is Probability Sampling by using the Simple Random Sampling method. Respondents are taken randomly then 150 respondents from culinary entrepreneurs in the City of Mataram were obtained. The response is collected by using questionnaires which are statistically analyzed by a simple linear regression test resulting regression equation: $\mathrm{Y}=4.746+0.496 \mathrm{X}$. Findings: according to the results using Statistical Product and Service Solutions (SPSS), there are positive and significant effects of the optimization digital marketing in increasing sales volume $(R$ value $=0.721$ ). It means that the digital marketing use optimization as independent variables contributed 72.1 percent of the dependent variable, namely the volume of sales; while the remaining 27.9 percent is influenced by other variables.
\end{abstract}

Keywords: Digital Marketing, Sales Volume, MSMEs, Mataram, Indonesia.

How to cite this paper: Abdurrahman, Anggriani, R., \& Bagus Faizal IS, R. (2021). Optimization the Use of Digital Marketing in Increasing Sales Volume at MSMEs in Mataram. Universal Journal of Business and Management, 79-89. Retrieved from https://www.scipublications.com/journal/index.php/ujbm/article/view/114

Received: August 12, 2021 Accepted: September 16, 2021 Published: September 17, 2021

Copyright: (C) 2021 by the authors. Submitted for possible open access publication under the terms and conditions of the Creative Commons Attribution (CC BY) license (http://creativecommons.org/licenses /by/4.0/).

\section{Introduction}

The development of information and communication technology nowadays greatly affects community activities without being limited by distance, space and time. Various small to large business activities take advantage of this development in running their business. Digital Marketing is a marketing medium that is currently in great demand by the public to support various activities carried out. Little by little, business people began to leave the conventional / traditional marketing model and switch to modern marketing, namely digital marketing. With digital marketing, communication and transactions can be done at any time (real time) and can be global because digital marketing is a marketing activity including branding that uses various kinds of social media networks [1].

Internet users continue to increase every year. Based on the results of a survey conducted by the Indonesian Internet Service Providers Association [2], internet users in Indonesia increased 10-12 percent in 2018 compared to the previous year. In total, internet users reached 171.17 million out of a population of 264.16 million. It is undeniable that the growth of internet users in the republic cannot be separated from the development of telecommunications infrastructure, both by the government and by massive telecommunications companies. This is also used by entrepreneurs to develop their business via the internet by promoting or marketing their products in various parts as long as the area has internet access.

The use of social media as a media to promote products is not only an additional marketing activity, but also an integrated communication mechanism that strengthens the impact of each function within an organization by leveraging the power of human networks through a platform [3]. Several studies have shown a link between the use of digital media, such as social media and sales volume. The increase in sales by of 10 to $50 \%$ after using social media as a marketing tool was felt experienced by most MSME's [4]. This is supported by statistical data that the use of social media in opening social networking 
sites in urban or urban areas such as Facebook is around $66.77 \%$, Twitter is $77.85 \%$, Path is $84.91 \%$ and Instagram is around $68.81 \%$ [5].

Each type of social media used has its own characteristics for advertising and promoting goods or services. For example, Facebook is the fastest growing social media platform. According to research from We Are Social media in collaboration with Hootsuite in January 2019, Facebook has the highest penetration of the social media category that is most actively used as an advertising medium, amounting to $81 \%$ or 130 million users. Its reach is wide and how to operate it is relatively easy. Businesses only need to create content in the form of descriptions, images or videos, find friends, sell groups and so on. While Instagram is in second place, which is actively used as an advertising medium by $80 \%$ or around 62 million users, Instagram prioritizes visual displays (images or videos) which are equipped with captions as an explanation. Several studies related to the use of social media Facebook and Instagram as a promotional tool have been carried out by marketing experts and experts. Research conducted by [6] is related to the effectiveness of promotion on social media using Instagram. The results have proven to be effective in increasing consumer purchases. Similar research was also conducted by [7] with the title "the influence of social media on selling local snacks online." This study focuses on the use of Facebook which has a dominant influence on the sale of local products online.

Product marketing with an online promotional strategy, especially through digital marketing, can increase sales widely if it is done consistently and is able to maintain the quality of the products produced. Consumers will also find it easier to find information about the products they want to buy because they don't need to be face to face in person. The Ministry of Communication and Information encourages MSMEs to take advantage of digital platforms as a medium for marketing their products. This can enlarge their business, both in terms of size and type of product produced, including marketing their products outside the region. This digital transformation is one of the ways for MSMEs to rise in the midst of the 2019 corona virus pandemic, known as covid-19 [5].

Since covid-19 emerged in early February 2020, business actors have closed their operations. This has an impact on the number of employees who are sent home, and many of them start working from home. This condition caused the Indonesian economy to decline, including in West Nusa Tenggara. Various efforts have been made by the NTB provincial government in dealing with the problem of economic downturn, one of which is by empowering MSMEs through a stimulus fund of Rp. 80 billion to strengthen the production sector or community industry, from the upstream to downstream industries including MSMEs [8].

Prior to the existence of Covid-19, the number of MSME players in the City of Mataram continued to increase from year to year. According to the mapping results of the West Nusa Tenggara Province MSMEs and Cooperative Office in collaboration with the NTB Province Central Statistics Agency in 2019, the development of the number of MSMEs in Mataram City increased by 4.33 percent. If viewed from the number of increases each year, the increase in the number of MSMEs in 2015 was 57,948, then in 2016 there were 58,026, in 2017 there were 58,139, and in 2018 there were 58,146 MSMEs. This means that increasing the number of business actors in this sector is very strategic if it is developed to strengthen the structure of the national economy in increasing people's income amidst the covid-19 pandemics.

The importance of this research is to increase the sales volume of MSMEs in the city of Mataram by optimizing promotional strategies through digital marketing. This is done so that business actors are able to survive during a pandemic, besides that the use of social media by the community has increased significantly since the outbreak of this outbreak, so many people do not want to interact directly to avoid covid-19 transmission, so that this moment can be used by MSME players in marketing their products online. Based on the last recorded statistical data in 2018, the number of MSMEs in Mataram City was 
58,146 with the classification of micro-scale businesses totaling 46,328 , small 11,007 , medium 632 and large scale 179 business actors [8].

Based on the above background, the researcher is interested in conducting research with the title "Optimizing the Use of Digital Marketing in Increasing Sales Volume at MSMEs in Mataram City". Business actors must be able to adapt to the conditions of economic uncertainty due to the Covid-19 pandemic. The optimization use of information and communication technology in running a business during a pandemic, in this case social media, is a new breakthrough in running a business to increase sales volume. This needs to be studied by researchers. How much influence does the use of digital marketing have on the sales volume of MSMEs in the city of Mataram. There are many things that affect sales volume, so in this study the authors limit only the use of social media which is often used in marketing its products which can have an impact on sales volume. As for the limitations on the object of research, the researcher focuses on MSME actors engaged in the culinary sector in the City of Mataram, based on statistical data from the Mataram City Revenue Service in 2018 there are 411 business actors engaged in the culinary industry.

Based on the description above, the problems raised in this study are: Is there an effect of the use of digital marketing on increasing the sales volume of MSMEs in the city of Mataram. Then, the objectives of this study are: To identify how much influence the use of digital marketing has on increasing the sales volume of MSMEs in the city of Mataram..

\section{Materials and Methods}

This research design uses a quantitative approach that tests certain theories by examining the relationship between variables. The variables can be measured by research instruments, so that data consisting of numbers can be analyzed based on statistical procedures [9].

This study uses two variables, namely the independent variable $(X)$ digital marketing, while the dependent variable $(\mathrm{Y})$ is the sales volume.

\subsection{Independent Variable}

The independent variable in this study is digital marketing which is related to the optimization of the use of social media such as Facebook, Instagram, Twitter and Youtube as a marketing medium in order to attract consumer attention, interact and transact with customers. The indicators of digital marketing variables are:

- Attention: includes attention to the way of promotion and the amount of social media used

- Costs: includes expenses spent during the month to promote on social media

- Duration: includes the period of time and length of time using social media

- Frequency: includes the frequency of using and promoting through social media

\subsection{Dependent Variable}

The dependent variable in this study is the sales volume. Where the sales level in question is the sales achievement expressed in quantitative terms in terms of physical or volume.

\subsection{Population and Sample}

According to [10] Population is a generalization area consisting of objects / subjects that have certain qualities and characteristics that are determined by the researcher to be studied and then draw conclusions. While the sample is part of the number and characteristics of the population.

The population in this study were MSME players engaged in the culinary business in the City of Mataram. From the statistical data of the Mataram City in 2019, there were 411 MSME players engaged in the culinary industry. In this study, the determination of 
the sample used is Probability Sampling; Simple Random Sampling where the respondents are SMEs engaged in the culinary industry who have been running their business for at least one year, using social media as a marketing medium. The types of social media referred to are Facebook, Instagram, Whatsapp, Twitter, Website, Email, Youtube, and others. The number of samples used was 150 respondents obtained from the Slovin formula with a tolerance limit of $10 \%$.

\subsection{Types and Sources of Data}

The type of data in this study is quantitative data, while the data sources used in this study consisted of 2 sources, namely:

1. Primary data is data obtained directly from respondents who are the subjects of the study. Primary data is obtained by distributing questionnaires online and offline to culinary entrepreneurs and,

2. Secondary data, namely supporting data obtained from journals, literature books and other documents related to research problems.

Then the data collection technique uses a questionnaire either directly or offline or via online using google form, and using documentation techniques. The documentation technique requires writing tools to print out questionnaires as well as recording other documents as a means of collecting data that will be sent to respondents to see how much effect of optimalization the use of digital marketing has on increasing the sales volume of MSMEs in the City of Mataram.

\subsection{Data Analysis}

This study uses a Likert scale. Likert scale can measure attitudes, opinions, and perceptions of a person or group of people about social phenomena. The questionnaire in this study uses a 5-point scale with scores that can be given are Strongly Agree (SS), Agree (S), Neutral (N), Disagree (TS), Strongly Disagree (STS).

Hypothesis testing according to [11] explains that the significance measure of the support of the hypothesis can be used to compare the value of $t$-table and $t$-statistics. The hypothesis is supported or accepted if the t-statistic is higher than the t-table value or it can also be compared to the p-value with the $\alpha$ value used.

\section{Results}

This study was limited to Mataram, and performed on MSMEs engaged in the culinary industry, because of the limitations of time and cost, and is constrained due to the pandemic of corona virus disease, 2019. Thus, the samples were taken in this study as many as 150 respondents to fill out and answer questions and statements in the questionnaire about optimizing the use of digital marketing in increasing sales volume for MSME players in Mataram. The data obtained from the respondents is about, data on gender, age, duration of business, education level, type of product, social media that was first used, social media most frequently used of total social media per day, pulse-per-month fee, a percentage increase of sales volume after using digital marketing and data respondent's. For more details, the respondent's classification will be explained as follows :

\subsection{Classification of Respondents Based on Gender}

Based on the results of the research that has been carried out, the classification of respondents by gender can be identified as follows(Table 1): 
Table 1. Classification of Respondents based on Gender

\begin{tabular}{cccc}
\hline No. & Gender & Number of Respondents & Percentage (\%) \\
\hline 1 & Men & 63 & 42 \\
2 & Women & 87 & 58 \\
& Total & $\mathbf{1 5 0}$ & $\mathbf{1 0 0}$ \\
\hline
\end{tabular}

Source: Primary Data Processed, 2020

Based on the Table 1 above, it can be seen that respondents with female gender are 87 respondents and more than male respondents with 63 respondents, which means that business actors in the culinary sector in Mataram City are more dominated by women.

\subsection{Classification of Respondents by Age}

Based on the results of the research that has been done, the classification of respondents by age can be identified as follows(Table 2):

Table 2. Classification of Respondents by Age

\begin{tabular}{cccc}
\hline No. & Age & Number of Respondents & Percentage $(\%)$ \\
\hline 1 & $<20$ Years & - & - \\
2 & $21-30$ Years & 83 & 55 \\
3 & 31-40 Years & 41 & 27 \\
4 & $41-50$ years & 22 & 15 \\
5 & $>50$ Years & 4 & 3 \\
& total & $\mathbf{1 5 0}$ & $\mathbf{1 0 0}$ \\
\hline
\end{tabular}

Source: Primary Data Processed, 2020

From the Table 2 above it is known that respondents with an age range of 21-30 years are more dominant, namely as many as 83 respondents, then with a range of 31-40 years as many as 41 respondents and a range of $41-50$ years as many as 22 respondents, the remaining 4 respondents are in the age range more than $>50$ years.

\subsection{Classification of Respondents Based on Last Education Level}

Based on the last level of education taken, the respondents in this study can be classified as in Table 3 below:

Table 3. Classification of Respondents Based on Last Education Level

\begin{tabular}{cccc}
\hline No. & Last education & Number of Respondents & Percentage (\%) \\
\hline 1 & Junior High School & 9 & 6 \\
2 & High School & 71 & 47 \\
3 & D3 & 12 & 8 \\
4 & S1 & 54 & 36 \\
5 & Others & 4 & 3 \\
& total & $\mathbf{1 5 0}$ & $\mathbf{1 0 0}$ \\
\hline
\end{tabular}

Source: Primary Data Processed, 2020

Based on the Table 3 above, it can be seen that the largest number of respondents based on education level were 71 high school graduates than 54 respondents with bachelor degrees and the rest were junior high school graduates 9 respondents, Diploma Three 12 respondents and Others as many as 4 respondents, who This means that the majority of culinary entrepreneurs in the city of Mataram have an average level of education at the high school and undergraduate levels. 


\subsection{Classification of Respondents by Type of Product}

Based on the type of product, the respondents in this study can be classified as follows(Table 4):

Table 4. Classification of Respondents by Type of Product

\begin{tabular}{cccc}
\hline No. & Types of products & Number of respondents & Percentage $(\%)$ \\
\hline 1 & Food and Drink & 94 & 63 \\
2 & Drink & 17 & 11 \\
3 & Snacks & 39 & 26 \\
& total & $\mathbf{1 5 0}$ & $\mathbf{1 0 0}$ \\
\hline
\end{tabular}

Source: Primary Data Processed, 2020

It can be seen that the largest number of respondents are entrepreneurs with a variety of food and beverage products, namely 94 respondents and snack food entrepreneurs as many as 39 respondents, while the rest are entrepreneurs with only the type of beverage products as many as 17 respondents. If viewed from the Table 4 above, entrepreneurs engaged in the culinary sector with the types of food and beverage products are the most prospective in Mataram City.

\subsection{Classification of Respondents Based on the Type of Tool Used}

Based on the type of media / tools used, the respondents in this study can be classified as follows(Table 5):

Table 5. Classification of Respondents Based on the Tool Used

\begin{tabular}{cccc}
\hline No. & Type of Media / Tool & Number of Respondents & Percentage (\%) \\
\hline 1 & Mobile & 136 & 91 \\
2 & Ipad / Tab & 11 & 7 \\
3 & Computer / Laptop & 3 & 2 \\
& total & $\mathbf{1 5 0}$ & $\mathbf{1 0 0}$ \\
\hline
\end{tabular}

Source: Primary Data Processed, 2020

The Table 5 above shows that the media or tools used to market the products of culinary entrepreneurs in Mataram are on average 136 respondents use cell phones or cell phones, then Ipad / tab is 11 respondents. Meanwhile, only 3 respondents used a computer / laptop. This means that cellphones are more widely used because they are more flexible and easy to carry everywhere, in contrast to Ipad / tab and computers / laptops which have larger sizes.

\subsection{Classification of Respondents Based on Social Media First Used}

Based on the type of social media that was first used, respondents in this study can be classified as follows(Table 6): 
Table 6. Classification of Respondents Based on Social Media First Used

\begin{tabular}{cccc}
\hline No. & Types of Social Media & Number of Respondents & Percentage (\%) \\
\hline 1 & Facebook & 113 & 75 \\
2 & Instagram & 25 & 17 \\
3 & Whatsapp & - & - \\
4 & Twitter & 10 & 7 \\
5 & Website & 2 & 1 \\
6 & E-mail & - & - \\
7 & Youtube & - & - \\
& total & $\mathbf{1 5 0}$ & $\mathbf{1 0 0}$ \\
\hline
\end{tabular}

Source: Primary Data Processed, 2020

From the Table 6 above, it can be seen that the social media that was first used to promote products from culinary business actors in Mataram were Facebook as many as 113 people, the rest using social media such as Instagram as many as 25 respondents, twitter as many as 5 respondents and website as many as 2 respondents. This means that, at first, respondents used Facebook for promotion more than other media.

\subsection{Classification of Respondents Based on Social Media Most Often Used}

Based on the type of social media that is most often used, respondents in this study can be classified as follows(Table 7):

Table 7. Classification of Respondents Based on the Most Frequently Used Social Media

\begin{tabular}{cccc}
\hline No. & Types of Social Media & Number of Respondents & Percentage (\%) \\
\hline 1 & Facebook & 107 & 71 \\
2 & Instagram & 39 & 26 \\
3 & Whatsapp & 3 & 2 \\
4 & Twitter & 1 & 1 \\
5 & Website & - & - \\
6 & E-mail & - & - \\
7 & Youtube & - & - \\
& total & $\mathbf{1 5 0}$ & $\mathbf{1 0 0}$ \\
\hline
\end{tabular}

Source: Primary Data Processed, 2020

The Table 7 above shows that the social media that is most often used in marketing is Facebook as many as 107 respondents, then Instagram with 39 respondents, 3 respondents using WhatsApp and 1 respondent using Twitter as the most frequently used marketing medium.

\subsection{Classification of respondents based on the duration of daily use of social media}

Based on the duration of daily use of social media, respondents in this study can be classified as follows(Table 8): 
Table 8. Classification of respondents based on the duration of daily use of social media

\begin{tabular}{cccc}
\hline No. & Time & Number of Respondents & Percentage $(\%)$ \\
\hline 1 & $<1$ hour & 6 & 4 \\
2 & $1-3$ hours & 38 & 25 \\
3 & $4-6$ Hours & 91 & 61 \\
4 & 7-9 Hours & 15 & 10 \\
5 & $>10$ Hours & - & - \\
& total & $\mathbf{1 5 0}$ & $\mathbf{1 0 0}$ \\
\hline
\end{tabular}

Source: Primary Data Processed, 2020

The average duration of the use of social media in updating business activities from the most respondents starting from 4 to 6 hours per day as many as 91 respondents, then from 1 to 3 hours per day as many as 38 respondents, 6 respondents answered less than one hour and 15 respondents answered that 7 to 9 hours per day are used for marketing on social media.

\subsection{Classification of Respondents Based on the Increase in Sales Volume}

Based on the percentage increase in sales volume after using digital marketing, respondents in this study can be classified as follows(Table 9):

Table 9. Percentage of Sales Volume Increase After Using Digital Marketing

\begin{tabular}{cccc}
\hline No. & Percentage of Increase & $\begin{array}{c}\text { Number of Respond- } \\
\text { ents }\end{array}$ & Percentage (\%) \\
\hline 1 & $0-10 \%$ & 3 & 2 \\
2 & $11-20 \%$ & 7 & 5 \\
3 & $21-30 \%$ & 6 & 4 \\
4 & $31-40 \%$ & 35 & 23 \\
5 & $41-50 \%$ & 28 & 19 \\
6 & $>50 \%$ & 71 & 47 \\
& total & $\mathbf{1 5 0}$ & $\mathbf{1 0 0}$ \\
\hline
\end{tabular}

Source: Primary Data Processed, 2020

Based on the Table 9 above, it can be seen that the percentage increase in sales volume after using digital marketing on average increased by more than $>50 \%$ with 71 respondents who answered so, then 28 respondents answered between $41-50 \%$, and 35 respondents answered between 31- 40\%, 6 respondents answered between 21-30\%, 7 respondents answered between $11-20 \%$, and 3 respondents answered $0-10 \%$ increase in sales volume after using digital marketing as a marketing medium.

\subsection{The Simple Linear Regression Analysis}

Simple linear regression analysis was carried out in hypothesis testing to determine whether or not the variable use of digital marketing had an effect on sales volume. The output results from simple linear regression calculations using SPSS software are as follows(Table 10): 
Table 10. Output Results of The Simple Linear Regression

\begin{tabular}{|c|c|c|c|c|c|c|}
\hline \multirow{2}{*}{\multicolumn{2}{|c|}{ Model }} & \multicolumn{2}{|c|}{ Unstandardized Coefficients } & \multirow{2}{*}{$\frac{\text { Standardized Coefficients }}{\text { Beta }}$} & \multirow[b]{2}{*}{$\mathrm{t}$} & \multirow[b]{2}{*}{ Sig. } \\
\hline & & B & Std. Error & & & \\
\hline \multirow[t]{4}{*}{1} & (Constant) & 4,746 & .730 & & 6,500 & .000 \\
\hline & Total_x & .496 & .039 & .721 & 12,648 & .000 \\
\hline & & & $R=0.721$ & & & \\
\hline & & & $\mathrm{T}$ table $=1.655$ & & & \\
\hline
\end{tabular}

Source: Primary Data Processed, 2020

Based on the output Table 10 above, the regression equation model is obtained as follows:

$$
\begin{gathered}
\mathrm{Y}=\mathrm{a}+\mathrm{bX} \\
\mathrm{Y}=4.746+0.496 \mathrm{X}
\end{gathered}
$$

From the coefficient of the simple linear regression equation above, it can be interpreted that for a constant value (a) of 4.746, it shows that if the optimization variable for the use of digital marketing is 0 or constant, it will increase sales by 4,746 units or by 474.6 percent. The optimization variable for the use of digital marketing is 0.496 , indicating that if the digital marketing variable increases by 1 , it will increase the sales volume by 0.496 units or 49.6 percent.

\subsection{Partial Test}

Partial hypothesis testing is intended to determine whether or not the independent variable is partially influencing the dependent variable. Based on the $t$ test results in the table above, the $t$ test results, digital marketing variable $(X)$ on sales volume with sig. 0.000 $<\alpha=0.05$ and $t$ count 12.648> $t$ Table 1.655. Then the amount of contribution from the independent variable $(\mathrm{X})$ to the dependent variable $(\mathrm{Y})$ is $72.1 \%$, which means that the digital marketing variable has a significant and positive effect on sales volume, while the remaining $27.9 \%$ is influenced by other variables outside of this study.

\section{Discussion}

Based on the results of the regression test show that there is an effect of the independent variable $(\mathrm{X})$ digital marketing in increasing sales volume $(\mathrm{Y})$ with a contribution value of $72.1 \%$ so that it supports the $\mathrm{H} 1$ hypothesis, namely that there is an effect of digital marketing in increasing sales volume in MSME business actors in Mataram City in particular engaged in the culinary field. This is a competitive advantage for entrepreneurs if the use of digital marketing is optimized to improve the performance of their business [12].

Optimizing the use of digital marketing in this research is a marketing activity carried out by MSMEs through social media such as Facebook, Instagram, WhatsApp, Twitter, website, email, YouTube, and others by distributing information about products being sold to their potential customers. The results of this study indicate that as many as 60.7 percent or as many as 91 respondents always use social media with an average duration of about 4 to 6 hours every day to promote their products. Thus, based on Table 9, most respondents stated that their sales volume increased by more than 50 percent after using digital marketing as a marketing medium.

The social media most frequently used by respondents in marketing their products is Facebook, which is 71.3 percent or 107 respondents, then there is Instagram by 26 percent or around 39 respondents who use social media, the rest use WhatsApp by 3 respondents and Twitter only 1 people who often use these media in marketing their products. This is because Facebook is circulating earlier and easier to access by anyone and has promotional features / content such as Facebook ads and users can join various groups. In addition, respondents in this study were more dominant with women, namely as many 
as 87 respondents or about 58 percent compared to male respondents as many as 63 respondents or about 42 percent because women were more likely to actively use social media than men. In addition, the results of this study indicate that the majority of respondents are in the age range of 21 to 30 years, namely around 55 percent or as many as 83 respondents are of productive age and belong to the millennial generation who are active on social media and are literate towards technology and information. MSMEs are currently very aware of the characteristics of their potential customers, so they use social media to communicate. These results support McQuail's theory of the emergence of new media, which includes digitalization and convergence of all aspects of the media. To adapt to the role of public publication in this case, business actors must follow industry developments and changes in consumer behavior. The benefits of optimizing the use of digital marketing in marketing products through social media are the best way to increase sales volume for MSME players to attract their potential customers.

\section{Conclusions}

There is a positive and significant relationship between digital marketing and sales volume, which is 72.1 percent, where Facebook is the first and most frequently used social media by respondents because it is easy to access and has many users and has promotional features that can be used. used by business actors. In addition, the potential to increase sales volume is even higher by utilizing various types of digital marketing that have characteristics and advantages in their features. So it can be said that the higher and optimal use of digital marketing, the higher the level of sales volume obtained. For future research, users can add independent variables apart from digital marketing to sales volume and expand analysis units such as e-commerce and marketplaces. In addition, further research is suggested to be able to expand the scope of research, not only in one business sector, but in all business fields to know the tendency of what factors can increase sales volume.

\section{Author Contributions:}

Abdurrahman, as the first author to carry out the research activity, Rini Anggriani, as the second to fourth writer who has done the editing of the manuscript and review of the article, and Raden Bagus Faizal IS, as the corresponding author who has submitted the article, edited the manuscript and carry out the review process.

Funding: This research was funded by UNIVERSITAS BUMIGORA, funding agency names at https://sipp.universitasbumigora.ac.id/.

Data Availability Statement: Already mentioned in appropriate sections

Acknowledgments: This paper is dedicated to Almighty GOD who bestows HIS blessings in all walks of my life, and of course, the Bumigora University as a funding provider.

Conflicts of Interest: The authors declare no conflict of interest.

\section{References}

[1] R. dan J. T. Sanjaya, Creative Digital Marketing. Jakarta: PT Elex Media Komputindo., 2009.

[2] APJII,_Asosiasi_Pengguna_Jasa_Internet_Indonesia,"_2019. ～https://aptika.kominfo.go.id/2020/06/tingkatkan-pemasaranumkm-dengan-transformasi-digital/.

[3] O. Blanchard, Mengelola dan Mengukur Penggunaan Media Sosial pada Organisasi. Jakarta: PT Elex Media Komputindo., 2015.

[4] W. Purwidiantoro, M. H., Kristanto S.W, D. F., \& Hadi, “Pengaruh Penggunaan Media Sosial Terhadap Pengembangan Usaha Kecil Menengah (UKM)," EKA CIDA 01, vol. 1, pp. 30-39, 2016.

[5] Kominfo, Booklet Survey TIK. 2020.

[6] and A. Khairani, Zulia, Efrita Soviyant, “Efektivitas Promosi Melalui Instagram Pada UMKM Sektor Makanan dan Minuman Di Kota Pekanbaru," Benefita 03, vol. 03, pp. 239-247, 2018. 
[7] I. Handaruwati, "Pengaruh Media Sosial Terhadap Penjualan Produk Camilan Lokal Secara Online," Bul. Business and Manag., vol. 03, pp. 41-52, 2017.

[8] Diskop.ntb, “Jumlah UMKM se-NTB, Data BPS tahun 2006-2017," Diskop.ntb.go.idiskop.ntb.go.id, 2018. http://diskop.ntbprov.go.id/jumlah-ukm-se-ntb-data-bps-tahun-2006-2017/\%5C.

[9] J. Creswell, "Qualitative, quantitative, and mixed methods approaches," in Research design, 2013.

[10] Sugiyono, Metode Penelitian Kuantitatif, Kualitatif, dan RED. Bandung. Bandung: Alfabeta, 2018.

[11] W. Abdillah and J. Hartono, "Partial Least Square (PLS) Alternatif Structural Equation Modeling (SEM) in business research," Andi Offset, 2016.

[12] A. Abdurrahman, "Establishing Competitive Advantage to Improve Bussiness Performance," J. business and economics Indones., 2018, doi: 10.37673/jebi.v3i1.27. 